\title{
Structuring the Potential Losses from Vandalism; Actions of Insurers Confronted with the Insecurity Resulting from Vandalism
}

\author{
Sonia Guelton*
}

\author{
Ecole d'urbanisme de Paris, Lab'Urba, France
}

\begin{abstract}
Social disturbances have occurred repeatedly in recent years in several countries. The number of incivilities is important from a social point of view as long as they often concern fragile populations, the poorest, and small shops and businesses. In the meantime, there are concentrated in deprived areas where it is all the most important to prevent exclusion and desertification. The risk connected with vandalism is a risk of social exclusion and economic division for the territories. The article tries to characterize the spatial concentration of crime. It questions the action of insurances in the reduction of spatial discrepancies and social injustice.
\end{abstract}

Keywords: Social disturbances, socio-economic costs, territorial inequality, risk, France.

\section{THE INCREASING PHENOMENON OF VANDALISM IN URBAN AREAS}

Social disturbances have occurred repeatedly in recent years in France, the United States, and several countries in Europe, similar to the events in Brixton in the United Kingdom in 1981.

These events have alarmed the public because of their unexpected nature and the level of the disorder they cause, without their origin being well known nor the manner in which they develop. Insurers are well aware of these phenomena because of their contributing to indemnities for damages. In France for 10 days of riots in November 2005, they have estimated 150 million euros paid in indemnities. In England, "Home Office" estimates around $£ 500,000$ damage suffered in 2001 (Home Office, 2003).

These events are merely a concentrated manifestation in time of more frequent attacks, though less publicized, on shops, vehicles or even people in public spaces. A feature of these events is that they also are highly concentrated in space. The urban riots, like other violent attacks, take place mainly in the center of cities, near commercial areas, and in the heart of wards dominated by a poor, immigrant and unemployed population.

The urban specialist looks at this issue carefully. He questions the spatial concentration of crime (Brantingham and Brantingham, 1994) which exacerbates the disparities between urban areas and jeopardizes the harmonious development of a city. He is concerned about the social injustice which

*Address correspondence to this author at the Ecole d'urbanisme de Paris, Lab'Urba, France; Tel: +33 1714080 79; E-mail: guelton@u-pec.fr characterizes it (Wikström Per-Olof, 1995). The areas affected are also the poorest neighborhoods! Vandalism pushes out those who can afford to leave these places, merchants avoiding opening their shops there. Only those who have no other choice remain. Vandalism thus reinforces social exclusion.

Following Brand and Price (2000), Cohen (1990) Cohen, Millerj and Rossman (1994) and Waters, Hyder, Rajkotia, Basu, Rehwinkel, Butchart (2004) the article focuses on the cost of damages and the impact on territorial inequalities. In order to understand who bears the cost of damages resulting from vandalism, an analysis has been conducted on insurance data. It then provides some elements of methodology in order to make use of cross-referenced economics and spatial data. Apart from the response to the measure of the vandalism costs for the society, the analysis levels major questions on the contribution of the private and the public sectors in the distribution of costs between people and places. In accordance to the statement made by Association of British Insurers (2003), it aims at answering the questions: do insurers concentrate the cost on the poorest people? Do they help to manage the risk and contribute to prevent or reduce costs between regions?

The article is organized as follow: Section 2 gives some understanding of the phenomenon of vandalism and the relativity of the picture provided by the "official" statistics. Data from insurers give additional information which helps to understand the risk of vandalism. Section 3 aims at describing the overall cost of vandalism. Only a small part of the true cost is generally considered. Speaking about "the cost of vandalism" (Godefroy et Palle, 1998) leads to investigate the hidden part of the iceberg (Water and al., 2004). Section 5 deals with the core question of 
Table 1: Some Urban Riots in France and England in Recent Years

\begin{tabular}{|c|c|c|c|}
\hline \multicolumn{2}{|c|}{ France } & \multicolumn{2}{|c|}{ England } \\
\hline 1990, October & Vaulx en Velin & & \\
\hline 1991, March & Sartrouville & & \\
\hline 1991, May & Mantes la Jolie & & \\
\hline 1993, November & Melun & 1995 & Bradford \\
\hline 1997, 2 November & Lyon & & \\
\hline 1997 & Dammarie les Lys & & \\
\hline 1998, 13 December & Toulouse & & \\
\hline 1999 & Vénissieux & 2001, March, May & Huddersfield \\
\hline 1999 & Montauban & 2001, 15 April, July & Bradford \\
\hline 2000, 12 July & Montbéliard & 2001 & Burnley \\
\hline 2003, 3 March & Nîmes & 2001 & Oldham \\
\hline 2003, December & Avignon & & \\
\hline 2005, October, November & France & 2005 & Birmingham \\
\hline
\end{tabular}

Sources: INHES/ OND, 2006, Home Office, 2003.

social justice and spatial inequality. It gives some information on the real payers, those who support the final cost of vandalism, and argues whether insurers or the public sector help to reduce the burden for the victims.

Our study deals essentially with France in 2005. We have focused our study on damage to the property of merchants and local authorities. In reality, they suffer a large share of the assaults and correspond to the identified insurance contracts. The stakes of attacks on people are heavy, but they deserve special treatment in terms of accountability and human health. We could get into data from insurers. Although they generally do not provide spatialized data, the importance of the damage in 2005 has led to new information issues. We also conducted several interviews with insurers and some local authorities who specially suffered important damage. The collected material will not give exhaustive information although it helps identify major trends and equilibrium.

\section{WHAT IS OUR UNDERSTANDING OF RISK?}

Knowing the cost of vandalism involves understanding the acts themselves.

\section{What is the Nature of the Events?}

There is no single definition of vandalism but there is a convergence of criteria between those of sociologists, the police, lawyers, and ultimately insurers.
Sociologists (Lagrande, Perreti, Pottier, Robert et Zaubermann, 2000) have an approach to vandalism that seeks to characterize the origin of the acts, their motives or the conditions within which they occur. For them, vandalism is a socio-political phenomenon that has its origins in an inadequate educational and demographic context (Fijnaut, Goethals, Peters and Walgrave, 1995).

The police (for example the British Home Office, Police Violence Report in the US, monthly) records crimes and violations based on the statements of victims (Maher \& Ryan, 2000).

In France, (Direction centrale de la police judiciaire, 2006) Police has a nomenclature within which urban violence can be identified by two criteria: the nature of the act, and their location. The most frequently reported events are robberies and assaults on public roads (in purse snatching, theft of two wheeled vehicles and cars, theft of trailers), damage to buildings or intrusion into buildings and assaults on persons on public roads. These statistics can be divided into 9 categories of offenses that are presented in Table 2. Only those that result in damage to property hold our attention.

Lawyers (JusrStats, 2003, Geason \& Wilso, 1990) analyze vandalism depending on the seriousness of the acts and their consequences. Most attacks do not have serious consequence for property and people. They differ from brutal assaults or use of force that require the intervention of law enforcement and medical care. 
Table 2: National Indicator of Urban Violence in France, by Number of Incidents, 2005

\begin{tabular}{|l|c|r|}
\hline 1 & Burning of vehicles & 45588 \\
\hline 2 & Burning of public property & 6996 \\
\hline 3 & Burning of trash receptacles & 30040 \\
\hline 4 & Violence against security, emergency, and health services & 5143 \\
\hline 5 & Throwing of projectiles & 9063 \\
\hline 6 & Occupation of halls of buildings & 313 \\
\hline 7 & Destruction of furnishings of buildings & 7893 \\
\hline 8 & Gang fights & 435 \\
\hline 9 & Drag racing & 4735 \\
\hline
\end{tabular}

Source: 2006 report of the Observatoire National de la Délinquance.

Insurers (Association of British Insurers, 2003, FFSA, 2006) do not always identify the origin of the damage, but the nature of the claim itself. Vandalism covers, mainly in their view, events of public gatherings, in cases of riots or terrorism, which correspond to acts taking place together, unlike isolated and random acts. In terms of property damage, acts of vandalism also concern damage to vehicles (wipers and mirrors broken, slashed tires, scratched body), buildings ("tagging", breaking and entering without theft), fires in common parts of buildings, broken store windows, computer piracy.... A common feature of vandalism is that the one responsible is rarely identified. When there is compensation, the acts remain most often at the expense of the insurer.

\section{What are the Statistics of Risk?}

They come chiefly from police departments and focus on the number of acts reported. It is clear that damages to public property and thefts in public places are increasing.

Insurers have released data for the riots of November 2005. These data distinguish between general claims and arson of vehicles. They permit quantifying the cost of compensation for damage.

These statistics also reveal the spatial concentration of claims. The geographical data are still recent and, in the case of insurers, reflect only the riots of November 2005. Yet they demonstrate for this period a

Table 3: Some Figures on Crime Reported from 2004 to 2006, France

\begin{tabular}{|c|c|c|c|c|}
\hline & & 2004 & 2005 & 2006 \\
\hline E & Total reported violations, metropolitan France & 3825442 & 3775838 & 3725588 \\
\hline \multicolumn{5}{|c|}{ including } \\
\hline a. & Thefts against individuals in their residence & 208126 & 205875 & 203747 \\
\hline b. & Thefts against industrial, commercial or financial establishments & 88661 & 82415 & 83520 \\
\hline c. & Thefts against individuals in public locations or premises & 449762 & 467413 & 457771 \\
\hline d. & Total Thefts & 746549 & 755703 & 745038 \\
\hline e. & Arson of private property & 29978 & 43231 & 38027 \\
\hline f. & Arson of public property & 5069 & 7109 & 5916 \\
\hline g. & Total Arsons & 35047 & 50340 & 43943 \\
\hline h. & Destruction or damage of private property & 172959 & 175415 & 161374 \\
\hline i. & Destruction or damage of public property & 43056 & 46192 & 44608 \\
\hline j. & Destruction or damage of private vehicles & 256290 & 263243 & 243489 \\
\hline $\mathrm{k}$. & Total destruction & 472305 & 484850 & 449471 \\
\hline
\end{tabular}

Simple or violent thefts, armed robberies are not counted.

Source: extracts from statistics on crimes and delinquencies, ministère de l'intérieur, 2004, 2005, 2006. 
Table 4: Urban Violence in France in 2005, Reported by the Insurers

\begin{tabular}{|c|c|c|c|}
\hline & Automobile & Non automobile & Total \\
\hline \hline Number & 8230 & 1761 & 9991 \\
\hline Cost in 1000€ & 31900 & 115977 & 147877 \\
\hline
\end{tabular}

Source FFSA.

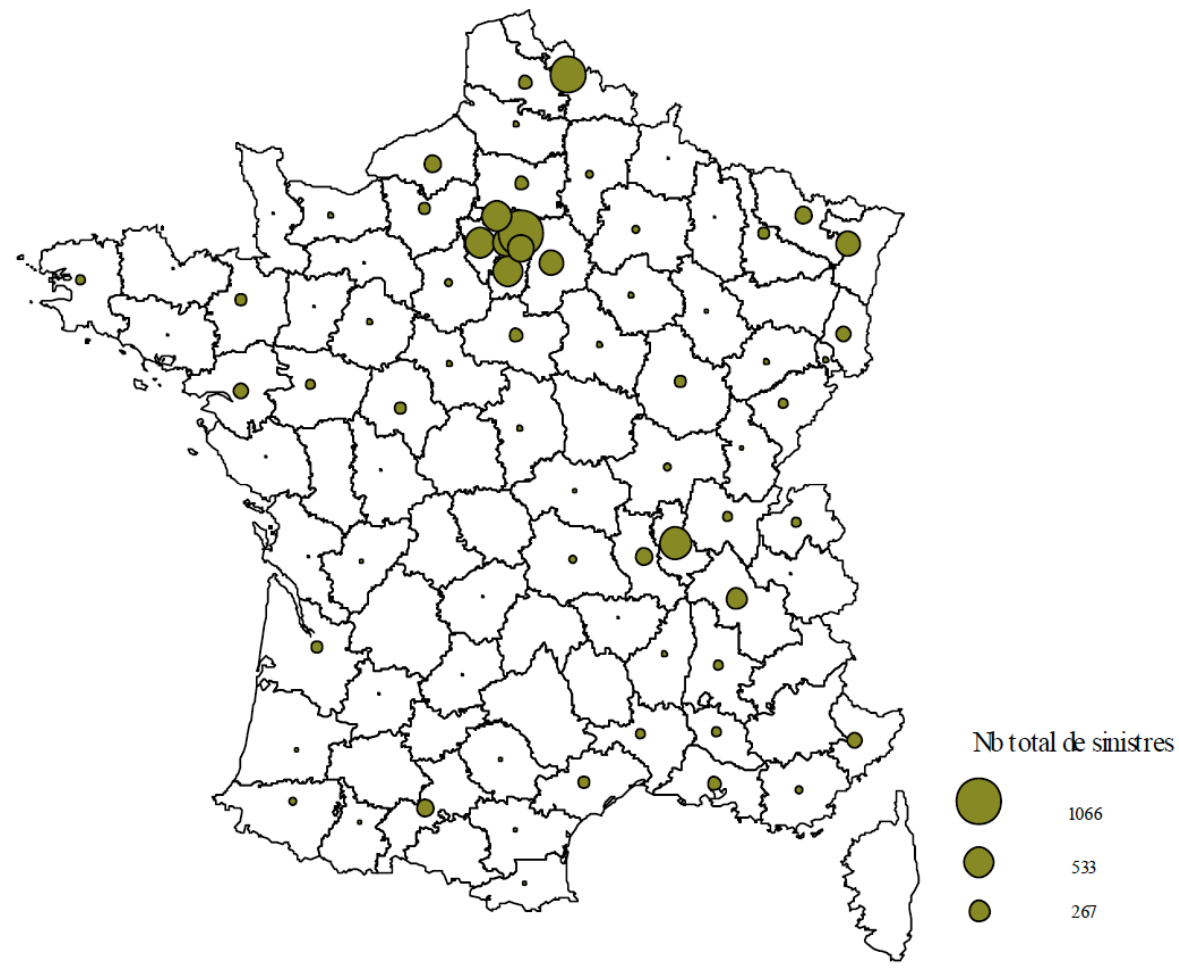

Carte 1: Claims made to insurers in October - November 2005, source FFSA.

concentration of claims over a dozen departments, those of the lle-de-France and the major cities: Strasbourg, Lyon, and Lille.

The figures showing the reported acts constitute only a part, relatively small, of the actual acts. Recalling that insurers require in principle, prior to compensation for a theft or damage, proof of a complaint to the police, Studies (Cohen, Millerj and Rossman, 1994; Bui-Trong, 1993) show that victims routinely do not report attacks, neither with the police or gendarmerie nor with insurers. A significant number of attacks therefore escape our examination. A study for the Ministry of Justice (Lagrange, Perreti, Pottier, and Zaubermann, 2000) estimates that in 7 attacks out of 10 , acts of vandalism are minor events that require no assistance and the victim does not report them. Insurance would be used only in 2 cases of property damage out of 10 . The same phenomenon is demonstrated in England (Association of British Insurers, 2003, and Brand and Price, 2000), or in the reports of seminar M.O.R.E. (see
International Association for the Study of Insurance Economics).

It is necessary to recognize that a large number of people are not insured or not insured sufficiently (Dubourg and Hamed, 2005). Except in a few cases, insurance is not compulsory and the need for insurance not readily admitted. Moreover, the cost of the premium is a deterrent for some. These two phenomena occur together in troubled neighborhoods of large cities and make people more sensitive when malicious events take place there (Wikström Per-Olof, 1995).

\section{THE OVERALL COST OF VANDALISM}

These observations on recognizing the facts of vandalism lead to the question of overall cost (seminar M.O.R.E., op. cit.). If a small part of vandalism can only be identified, how does one assess the submerged part of the iceberg? What must an "global" analysis of it take into account? 


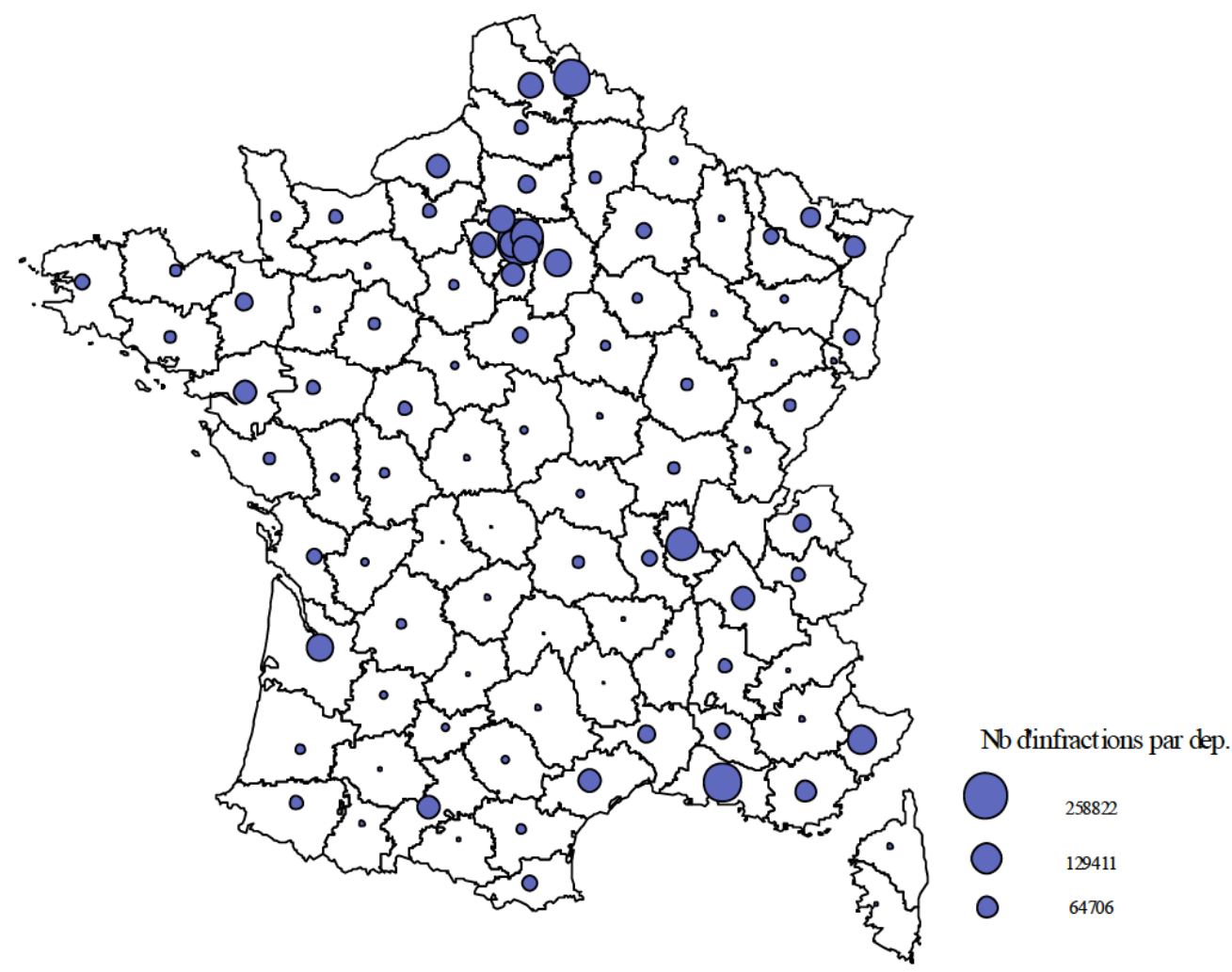

Carte 2: Violations reported during the year 2005, Source : ministère de l'intérieur.

First, it should be noted that an analysis of the overall cost cannot simply leave out revenue, but should deduct the costs.

Several sources of revenue can be identified. Revenues for the insurer consist primarily of premiums paid by the insured. The revenue for public authorities comes from fines levied on people who committed acts and were identified (Godefroy and Palle, 1998). Revenues for the victims are compensatory indemnities. In these cases, the gains for some cancel the losses for others. It is likely that "profits" also can occur. Some believe that actual revenue can come under the guise of insurance fraud, or economic benefit in the form of moral satisfaction. Yet, unlike intentional theft, the aim of the malevolent actor is not to take something to get an advantage. It seems the revenue of vandalism can be ignored.

According to economics analysis (Godefroy and Palle, 1998, Brand and Price, 2000, Brandon, 2000) the costs of vandalism take three forms: the cost of damages, indirect costs induced by losses and the cost of prevention and protection.

- The cost of damages is the "visible" part of vandalism. It consists of the costs of repairing damaged property. These expenses are borne by the owner of the property. As a result of judicial proceedings, they are generally transferred to the person who committed the act. When the owner of the property is insured, the insurance bears a part of the cost.

The cost of the damage extends to repair costs for any loss or damage associated with the identified principal act. These incidental damages can be very important, especially when dealing with people or activities: a building fire can result in broken windows in other nearby buildings, as well as accidents, injuries. The damage of a garage door can prevent the transport of a worker and translates, in this case, into a loss of business.

The declared cost of damages can be acquired from the insurers or from the courts.

- Indirect costs are borne by economic agents who are not directly involved in the claim. These indirect costs are difficult to identify. The link with vandalism is not always easy to demonstrate. The costs are often "socio-economic" and are difficult to translate into monetary terms. For example, damage to the entrances of a school can cause trouble at the arrival or the departure of children, as well as delays, accidents. Repairs carried out with urgency affect the 
planned work program, causing delays in turn and their share of inconvenience... Other consequences must be taken into account when residents avoid the street where the incident occurred, lengthening their journey, even moving away from the area. These "social" costs have been the subject of an international study on interpersonal violence (Waters H., 2004). But applying these costs to the actual event is rarely done.

- The costs of prevention and protection are not related to the occurrence of an act of vandalism, even though they are often initiated, after a loss, to prevent their repetition.

Protection consists of taking steps to limit the consequences of malevolent acts: curtains on windows, locks strengthened, using special "antigraffiti" paint, parking vehicles in covered and closed garages. These expenses are paid by property owners.

Prevention aims to reduce the occurrence of malevolent acts. It is recognized that public lighting, police presence, the existence of "foot patrols" soothes the social climate. Initiatives are most often organized and paid for by the local public authorities. They accompany private initiatives that occur in deprived urban areas. The insurer does not get involved much in these measures and does not contribute to expenses. But he can play a role as a partner which will be covered in section 5 .

Evaluations of the "cost of crime" are given in Table 5. They differ in the sphere of costs, public or private, taken into account. Pain and suffering are evaluated in Anglo-Saxon studies (Dubourg and Hamed, 2005), as recommended now by the European Commission. But the social costs are not counted.

\section{WHO PAYS: BETWEEN INSURERS, GOVERNMENT AND VICTIMS?}

The analysis of contracts signed in France by several local authorities or explained by insurers in their official documents or in interviews gives insights into how insurers indemnify claims from vandalism. It identifies three situations, depending on the size and frequency of claims. In each case, the sharing of costs between the insured and the insurer is different.

- Small incidents are not covered by insurance because they do not exceed the deductible amount. Contracts ensure that the deductible amount is adapted to the frequency of events: if the insurer must intervene too often for low indemnities, he cannot recover his administrative costs. Those insured must establish a system of self-protection or repair damages on their own.

Example: in a local government in lle de France, the deductible condition for breaking Glass insurance is $2000 € /$ claim - The cost of self-insurance is estimated $37000 € /$ year.

As for urban riots, several French insurers have openly admitted that they had to reimburse claims on individuals' vehicles without subtracting the deductible amount. This media operation certainly has weighed on the accounts of insurers but did not affect their fundamental equilibrium. The ratio of payments versus premiums received is said by the auto insurance industry to be $83 \%$ in 2005 (according to FFSA, 2006).

An individual or a merchant who is particularly concerned about these events can still obtain a special clause providing for indemnity from the insurer. The surcharge for broken vehicular windows is not very

Table 5: The "Cost of Crime", Element of Evaluation, Examples

\begin{tabular}{|c|c|c|c|}
\hline & France & England & Canada \\
\hline \hline Overall cost/ year & 20 billion $€$ & 15940 million $£$ & 70 billion $\$$ \\
& .23285 million $€ 2007$. & .23766 million $€ 2007$. & .54368 million $€ 2007$. \\
\hline Cost of losses & & $63 \%$ & $67 \%$ \\
Insurance portion & $25 \%$ & $25 \%$ & Not evaluated \\
Victims: pain and suffering & Not evaluated & Not evaluated & $19 \%$ \\
\hline Indirect social costs & Not evaluated & $28 \%$ & $14 \%$ \\
\hline Justice and police prevention & $55 \%$ & $9 \%$ & JusrStats, 2003 \\
\hline Prevention: & & & \\
\hline Private portion & Godefroy and Palle, 1998 & Dubourg and Hamed, 2005 & \\
\hline Sources & &
\end{tabular}


Table 6: Opportunity for Insurance for Risks Linked to Vandalism

\begin{tabular}{|c|c|c|c|}
\hline frequency $\quad$ Cost & small & & large \\
\hline \multirow[t]{2}{*}{ Low } & $\begin{array}{l}\text { Defacing entryway to buildings } \\
(1000 €) \\
\text { Auto insurance }\end{array}$ & $\begin{array}{l}\text { Theft of vehicle }(2060 €) \\
\text { Burning of bus stop }(3500 €) \\
\text { Insurance }\end{array}$ & $\begin{array}{c}\text { Arson of public building } \\
\text { (1.5 to } 2 \text { million } € \text { in } 2005) \\
\text { Burning of warehouses }(9,4 \mathrm{M} €) \\
\text { Insurance }\end{array}$ \\
\hline & $\begin{array}{c}\text { Breaking automobile glass }(280 €) \\
\text { Burning of trash receptacle }(150 €) \\
\text { Graffiti } \\
\left.\text { (15 to } 60 € / \text { year } / \mathrm{m}^{2}\right) \\
\text { Auto insurance }\end{array}$ & $\begin{array}{l}\text { Burning of vehicle }(3000 €) \\
\text { Breaking of storefront windows (by } \\
\text { throwing projectiles.) Damage of } \\
\text { electronic equipment } \\
(15000 € \text {, or+) } \\
\text { Insurance }\end{array}$ & $\begin{array}{c}\text { Burning of public building during } \\
\text { riots ( } 1.5 \text { to } 2 \text { million } € \text { in } 2005 \text { ) } \\
\text { Refusal to insure }\end{array}$ \\
\hline
\end{tabular}

Source: author.

large and the insurance ratio is $82 \%$ (FFSA, annual reports).

- From our interviews, it appears clearly that incidents of average importance which occur repeatedly in some nonvolatile areas are generally covered by insurance contracts without any special mention. The frequency and cost of the event does not seem to reach levels that justify a special clause in individual contracts. The insurer covers any direct physical losses and their material accessories. The insured bears the cost in morale and fear of having the event happen again. He may then want to increase his safeguards and his own protective measures accordingly. Oftentimes the insurer himself encourages these measures. After an event he may increase his premium, or demand greater protection. Local authorities we have visited have seen their premiums increase by $10 \%$ in 2006 and their deductible amounts have grown more than $30 \%$.

Insurance contracts for merchants and local authorities, however, exclude the reimbursement of claims associated with riots, or provide such coverage at an additional cost and with a special deductible amount. (see following table).

These clauses have the effect of significantly reducing the share of compensation paid by insurance. They explain why a large proportion of small merchants and local authorities have recourse only to a minimum of insurance, preferring to guard themselves against the misdeeds of vandalism: private surveillance, early warning systems, and managing repairs. Most large companies and some local governments set up a prevention system based on security. One survey highlights the fact that French Authorities fall far short of public institutions in other European countries in terms of awareness of risk management!

- Urban riots also result in costly damages, rarely to the property of individuals and merchants, but heavy when the property of manufacturers or local authorities is affected. In November 2005, damages were suffered mainly by commercial enterprises. Some figures have been reported in the FFSA annual report: excavation contractors: 9.4 million euros, automobile dealers: 5.8 million euros, warehouses: 2.5 to 4 million euros, and some public buildings: city halls: $500000 €$, gymnasiums: 1.8 million, media centers, schools... At Bradford in 2001, 3 complaints were registered for activity centers and $£ 420000$.

These situations pose a problem for insurers because their high cost is associated with a high concentration of claims. In particular, insurers of local authorities have expressed their concern. In France, there are only a few insurers for this specialized clientele and the pooling of risks may no longer be effective (Sontag, 2005).

According to our survey, these problems reveal two attitudes on the part of insurers. The refusal to insure is a choice for the insurer. In practice, they operate by selecting clients by price. Thus merchants and local authorities have trouble finding an insurer when their location is suspect.

Another way to eliminate risky situations is to craft contractual terms of exclusion or above-prime. They have been applied systematically in the areas that experienced the events of November 2005. Limits on reimbursement per claim also are applied. 
Table 7: Elements of an Insurance Contract on the Property of Local Authorities, Examples from Seine Saint Denis

\begin{tabular}{|c|c|c|c|c|c|c|}
\hline \multicolumn{7}{|c|}{ 2005, in Euros } \\
\hline City & $\begin{array}{c}\text { City budget } \\
\text { running costs. }\end{array}$ & $\begin{array}{c}\text { Premium/ } \\
\text { year }\end{array}$ & Deductible amount & $\begin{array}{c}\text { Maximum indemnity } \\
\text { /claim }\end{array}$ & $\begin{array}{c}\text { Premium/ } \\
\text { budget }\end{array}$ & $\begin{array}{c}\text { Total claims in } \\
\mathbf{2 0 0 5}\end{array}$ \\
\hline \hline A & 53365000 & 74870 & Riots: 3800 & 150000 & $0.14 \%$ & 17100 \\
\hline B & 32627000 & 37600 & Theft : 1500 & $10 \%$ of damage & $0.11 \%$ & $0.29 \%$ \\
\hline C & 47889000 & 134000 & Theft : 4900 & 2000000 & 84050 \\
\hline D & 54493000 & 170000 & Vandalism : 40000 & 0 & $0.31 \%$ & 2600000 \\
\hline E & 30578000 & 112000 & Vandalism: 3800 & 30500 & $0.36 \%$ & $?$ \\
\hline F & 62976000 & 162500 & Theft: 2000 & 190000 & $0.25 \%$ & 280000 \\
\hline
\end{tabular}

Note: $100 \%$ of property is covered by insurance except for furnishings in one case. Sources: MINEFI, calculation by the author after research in Seine Saint Denis.

Governments bear a third part of the cost of vandalism. Lets look at this part carefully, through general figures and our interviews.

- At the local level, governments have a responsibility for their citizens. Some Local Authorities (regions) have a budget favoring victims of vehicular damage. In order to enhance community well-being, they participate in the repair of small damages. Some authorities clean graffiti, for example, or provide for the free removal of burned vehicles. For example, the city of Aix en Provence says it spends 1 million euros for the annual cleaning of graffiti.

- At the national level, the debate is about the responsibility of public authorities for the costs of urban riots. Insurers believe that crowds are within the responsibility of the central government and defend their position of a minimum indemnity. This opinion is, apparently, shared by the insurance profession in other European countries. Yet the French government's view differs. It agrees to intervene in order to help local governments handle their financial difficulties. It accepts the principle of providing financial aid to place merchants in deprived urban areas: part of the funds can be used to pay any additional costs of insurance, although these financial interventions are rarely requested. But the French government does not envisage a public system of covering losses during urban riots. The battle is played on the legal field. It is understood that the issue is also budgetary.

Table 8: Synthesis of Sharing the Costs of Vandalism, 2005, France

\begin{tabular}{|c|c|c|c|c|c|}
\hline & Victims & Insurance & Public Government & \multicolumn{2}{|c|}{ Incidents in 2005} \\
\hline & \multicolumn{3}{|c|}{ On a scale of 1 to 5} & Number & Cost declared to \\
\hline Burning of vehicles & 1 & 4 & & 45588 & $31,9 \mathrm{M} €$ \\
\hline Burning of public property & 2.LG. & 2 & 1.CG. & 6996 & $116 \mathrm{M} €$ \\
\hline Burning of trash receptacles .graffiti. & 4 & & 1. LG. & 30040 & - \\
\hline $\begin{array}{c}\text { Violence against security, emergency, and health } \\
\text { services }\end{array}$ & \multicolumn{3}{|c|}{ As a reminder } & 5143 & - \\
\hline Throwing of projectiles .breaking of glass. & 3 & 2 & & 9063 & As a reminder \\
\hline Occupation of halls in buildings .entry to buildings. & 3 & 2 & & 313 & As a reminder \\
\hline Destruction of urban furnishings & 5. LG. & & & 7893 & - \\
\hline Gang fighting & \multicolumn{3}{|c|}{ As a reminder } & 435 & - \\
\hline Drag racing & \multicolumn{3}{|c|}{ As a reminder } & 4735 & - \\
\hline TOTAL & 15 .dt LG 7. & 8 & 2 & 110206 & 147,9 M€ \\
\hline
\end{tabular}

Sources: estimates by author, OND, FFSA.

LG: local governments; CG: Central Government, M: million. 


\section{THE REDUCTION OF INSECURITY LINKED TO VANDALISM BY INSURERS}

If insurers avoid a significant part of the cost of vandalism, they do not remain indifferent to its overall importance.

Of course, they do not participate in the politics of preventing insecurity in France. They are sometimes solicited as part of "city politics," but the few attempts investigated remain a dead letter. As an example, in 1996, a proposed standard contract for merchants in distressed areas did not yield any results. Investigations carried out in deprived urban areas tend to show that attention is focused on relations with those insured to adjust reimbursements and reduce the occurrence of claims.

The question of reimbursement is difficult. It depends on the exposure to risk. Based on what is currently known about vandalism, the insurer does not seem to have numerous objective elements for analysis. When conditions are better known, for example, about jewelers or pharmacists, he may set in place a suitable contract, which manages the conditions of reimbursements based on events and measures of security. By targeting events according to their nature, the insurer manages to control spending: he pays for the broken window but not for thefts in the store. He may also make contracts for an entire professional group -a commercial chain, such as Mac Donald or LIDL- permitting a sharing between locations and lowering costs for the insured and risks to the insurer.

The actions of insurers contribute the most to reduce occurence of claims. We have identified an incentive in the clauses of the contract, and a presence, very discreet, alongside the insured for inducing risk management.

The insurer encourages his client to take measures of protection and prevention. The insurance contract for individuals and merchants is almost always concluded with conditions to reduce the severity of claims and deter excesses. The profession is involved in the design of certified equipment, given by AFNOR in France and the National Approval Council for Security Systems in the United Kingdom, such as storefront barriers or video surveillance. One can therefore appreciate the cohesiveness of the effort to improve prevention systems and encourage their installation. It is regrettable that insurers have stakes in companies distributing these systems, because it poses the problem of collusion. The limit of such measures is that the extra cost of the installation must be borne by the insured while the premium does not decrease proportionally with the installation.

For large enterprises and businesses, the insurer requests or conducts an audit even before signing the contract. Local governments often use an external auditor to prepare the contractual conditions. Even when the audit does not impose specific conditions, it contributes to information on risk and increases awareness by the insured of potential vulnerabilities. Deliberations with the insured allow the establishment of a system of responsive management. Eventually, the insurance contract also will be more responsive, cheaper and more effective.

In addition to contracting procedures, some insurers participate in the discussion of protection and prevention. Many publish guides, such as one on protection against vandalism for small businesses and offices in sensitive urban areas. They contribute to training days with their target clientele. They participate in discussions by attending professional meetings. From local authorities, Groupama is developing a set of specific services and contracts in prevention and management of crises. The SMACL hosts a think tank on legal risks for local authorities. These examples demonstrate that insurers position themselves alongside their clients to participate in their prevention effort and offer them in return contracts adapted for the management of risk.

When the insurer has a network of middlemen, they complement the interventions by a relationship tailored to the customer. In parallel brokers play the same role with greater independence. Their objective often is to improve their client's risk management in order to help in negotiations with the insurer.

These actions are part of a commercial network. Their effect on risk reduction is not measured. Their effect can be observed only over the long term, and through the resulting changes in behavior. Today in France, the awareness of businesses and local authorities remains incomplete in most cases. Contrary to what is done in the aftermath of floods, governments do not intervene in this arena. For floods, French legislation allows the insurer to apply a variable deduction depending on whether the town where the disaster occurred has or has not set up a plan for risk prevention. As long as vandalism is concerned, governments rely on the role of forced education in 
which the insurers participate. Both sides do not want to go beyond their competencies, but to push each other in their responsibilities. The game has begun!

Other solutions are envisaged to achieve better management of risks and costs. Discussions focus on the creation of a mutual fund or a fund for indemnifying victims, similar to the indemnification fund for natural disasters. Insurers and their clients remain the first contributors, by means of a guarantee from the state. The principle is not accepted in the field of urban riots. Insurers want a public fund. The issue of cost sharing between the public and private sectors is at the center of debate.

It is regrettable that the preliminary issue, that of cost-sharing between victims and others, and between the regions, is not addressed first. Insurers contribute by levies and refunds, a social and spatial sharing of the cost of vandalism. Public-private solutions that would allow the expansion of insurance coverage, between the limits of insurance and guarantees, would they not be more effective for social justice than responses based on a balanced budget!

\section{REFERENCES}

Association of British Insurers. 2003. Riot Damages Act 1886 Consultation: a Response by the Association of British Insurers, $\mathrm{ABI}$, http://www.abi.org.uk/

Betbeze, Jean-Paul et Bentoglio, Guilhem. 2005. L'Etat et l'assurance des risques nouveaux, rapport du groupe de projet TELEMAQUE pour le Commissariat Général du Plan, Paris, La Documentation française.

Bichot, Jacques. 2012. "Le coût du crime et de la délinquance " Etudes et analyses $n^{\circ} 8$, France, Institut pour la Justice.

Brand, Sam and Richard, Price. 2000. The Economic and Social Costs of Crime, London, Home Office Research Study 217.

Brandon, C. Welsh. 2000. L'application de l'analyse économique à la prévention du crime : éléments d'une approche nationale, Département de justice pénale, Université du Massachusetts à Lowell .http://www.prevention.gc.ca/.

Brantingham, Patricia L. and Paul J., Brantingham. 1994. "Location Quotients : Toward a Micro Analysis of Crime», Criminologie, vol. $27, \mathrm{n}^{\circ} 1,1994: 81-97$.

Bui-Trong, Lucienne. 1993. "L'insécurité des quartiers sensibles : une échelle d'évaluation "Les cahiers de la sécurité intérieure $\mathrm{n}^{\circ} 14$, août 1993 : p. 235 ;

Centre d'Analyse Stratégique. 2006. « Analyse : Les violences urbaines : une exception française ? Enseignements d'une comparaison internationale » Note de Veille $\mathrm{n}^{\circ}$ 31: 1-4

Cohen, Mark A., Ted R., Millerj et Shelli B., Rossman. 1994. "The Costs and Consequences of Violent Behavior in the United States", in Understanding and preventing violence: Consequences and control, edited by Albert J. Reiss, Jr., et Jeffery A. Roth, Washington, D.C., National Academy Press: $67-166$
Cohen, Mark A. 1990. "A Note on the Cost of Crime to Victims", in Urban Studies, 1990, n² 27: 125-132.

Crawford, Adam. 2001. "Les politiques de sécurité locale et de prévention de la délinquance en Angleterre et au Pays de Galles : nouvelles stratégies et nouveaux développements ", in Déviance et Société, 2001, Vol. 25, No 4 : 427-458

Délégation Interministérielle à la Ville. 2006. Rapport de l'observatoire national des zones urbaines sensibles

Dijk, Jan Van. 2009. Assessing Deviance, Crime and Prevention in Europe, France, CRIMPREV.

Direction centrale de la police judiciaire. 2006. Criminalité et délinquance constatées en France par les services de police et les unités de gendarmerie : année 2005, Paris; Direction centrale de la police judiciaire, 2 tomes

Dubourg, Richard et Hamed, Joe. 2005. The Economic and Social Costs of Crime against Individuals and Households 2003/04, Online Report 30/05, United Kingdom, Home Office, Research, Development and Statistics Directorate.

FFSA. 2006. Le marché de l'assurance automobile en 2005, Paris ;

Geason, Susan and Paul R., Wilso. 1990. Preventing Graffiti and Vandalism, Australian Institute of Criminology.

Godefroy, Thierry et Palle, Christophe. 1998. "Coût du crime. Une estimation monétaire des délinquances ", Paris, CESDIP, Etudes et Données pénales. 1998. n79;

Home Office. 2003. Riot Damages Act 1886, Consultation on options for review, http://www.homeoffice.gov.uk/inside/consults/ current/index.html

Huber, Michael. 2004. Reforming the UK Flood Insurance Regime, The Breakdown of a Gentlemen's Agreement, ESRC Centre for Analysis of Risk and Regulation, Discussion Paper $n^{\circ} 18$, London, The London School for Economics and Political Science.

JusrStats. 2003. $\mathrm{n}^{\circ}$ 2204-15, Division de la recherche et de la statistique, Canada, Ministère de la Justice;

Lagrande, Hugues, Perreti-Watel, Patrick, Pottier, Marie-Lys, Robert, Philippe et Zaubermann, Renée. 2000. « Une enquête sur les risques urbains, étude de préfiguration ", Paris, CESDIP, Ministère de la Justice Etudes et données pénales .2000 . $\mathrm{n}^{\circ} 81$;

Lapeyronnie, Didier. 2006. "Les émeutes urbaines en France, en Grande Bretagne et aux Etats-Unis, in Regards sur l'actualité $\mathrm{n}^{\circ} 319$, Paris, La documentation française : $5-14$;

Mahe, George \& John P. Ryan, ACAS. 2000. "Evaluating Claims costs arising out of Political Disorder and Civil Unrest", in Casualty Actuarial Society Forum, Vol Fall.

Mansion, Yves. 1999. "Les assureurs face au risque urbain " in Risques $\mathrm{n}^{\circ} 38: 17-18$

OCDE. 2003. Assurance et risques environnementaux: Une analyse comparative du rôle de l'assurance dans la gestion des risques liés à l'environnement, Presse de l'OCDE

Problèmes économiques. 2006. Dossier Assurance "Nouveau risques et assurabilité " in Problèmes économiques, mars 2006. $n^{\circ} 2-985: 1-34$

Risques. 1999. $n^{\circ} 38$, dossier "Le risque Urbain », Paris, LGDJ / SCEPRA : $6-20$

Schuler, Nina. 2001. Crime and Disorder Audit, report to Waltham Forest SafetyNet Partnership, Nacro, The Crime Reduction Charity.

Sontag Katjia. 2005. Le contrat d'assurance des communes, Paris, édition Le Moniteur, coll. Analyse juridique.

Waters, Hugh, Hyder Adnan, Rajkotia Yogesh, Basu Suprotik, Rehwinkel Julian Ann, Butchart Alexander. 2004. The Economic Dimensions of Interpersonal Violence, Geneva, Department of Injuries and Violence Prevention, World Health Organization. 
Wikström, Per-Olof. 1995. "Urban neighborhoods, victimization and fear of crime", Pp I-39 - I-55 in Changes in Society, Crime and Criminal Justice in Europe: a Challenge for Criminological Education and Research, Vol.1: Crime and insecurity in the city, edited by C. Fijnaut, J. Goethals, T. Peters and L. Walgrave. Netherlands: Kluwer Law international

Received on 09-03-2016

Accepted on 21-03-2016

Published on 11-05-2016

DOI: http://dx.doi.org/10.6000/1929-4409.2016.05.07

(c) 2016 Sonia Guelton; Licensee Lifescience Global.

This is an open access article licensed under the terms of the Creative Commons Attribution Non-Commercial License (http://creativecommons.org/licenses/by-nc/3.0/) which permits unrestricted, non-commercial use, distribution and reproduction in any medium, provided the work is properly cited. 